\title{
Invasion-mediated shifts in the macrobenthic assemblage of a rocky subtidal ecosystem
}

\author{
Jennifer R. Kelly ${ }^{1, *}$, Robert E. Scheibling ${ }^{1}$, Toby Balch ${ }^{1,2}$ \\ ${ }^{1}$ Department of Biology, Dalhousie University, Halifax, Nova Scotia B3H 4J1, Canada \\ ${ }^{2}$ Present address: Nova Scotia Department of Fisheries and Aquaculture, Halifax, Nova Scotia B3J 3C4, Canada
}

\begin{abstract}
We tracked changes in community composition that occurred with state shifts in the rocky subtidal ecosystem in Nova Scotia, Canada, from 1992 to 2008. At the beginning of our study, a dense aggregation of sea urchins was destructively grazing a kelp bed, leaving corallinealgae-dominated barrens in its wake. In subsequent years, the system underwent a series of state shifts mediated by mass mortality of sea urchins due to amoebic disease, defoliation of kelp by an invasive bryozoan Membranipora membranacea, invasion of the green alga Codium fragile ssp. fragile, and finally decline of $C$. fragile and recolonisation by kelps. Using multidimensional scaling (MDS), we found 4 macroalgal assemblage types (dominated by kelp, coralline algae, $C$. fragile, or a transitional mixture of species), each associated with a distinct invertebrate assemblage. Sea stars and kelp-grazing gastropods were associated with the kelp-dominated state; sea urchins, chitons and scale worms were most abundant in the barrens state; and small bivalves and amphipods were most abundant in the $C$. fragile-dominated state. Invertebrate diversity remained relatively constant despite dramatic shifts in the algal assemblage. Although the system was vulnerable to multiple perturbations between 1992 and 2002, the partial recovery of kelp beds and associated fauna by 2008 demonstrates some resilience in the longer term.
\end{abstract}

KEY WORDS: Alternative community states - Biological invasion - Codium fragile Kelp beds · Macrobenthic community structure $\cdot$ Membranipora membranacea $\cdot$ Sea urchins

Resale or republication not permitted without written consent of the publisher

\section{INTRODUCTION}

State shifts resulting in the loss of macroalgae due to destructive grazing, or defoliation following epiphyte outbreaks or oceanographic events, cause drastic changes in productivity, habitat structure and environmental characteristics of rocky subtidal ecosystems (Steneck et al. 2002, Graham 2004). These changes can decrease diversity and alter community composition of benthic invertebrates (Behrens \& Lafferty 2004, Graham 2004). However, when native macroalgae are removed by disturbance and replaced by opportunistic invasive algae, effects on the macrofaunal assemblage may be relatively minor if the invasive alga performs a similar structural role in the system (Forrest \& Taylor 2002, Britton-Simmons
2004, Schmidt \& Scheibling 2006, Strong et al. 2006, Raffo et al. 2009).

The rocky subtidal ecosystem off the Atlantic coast of Nova Scotia, Canada, has historically alternated between 2 states: kelp beds (mostly Saccharina longicruris and Laminaria digitata) and barrens dominated by sea urchins Strongylocentrotus droebachiensis and encrusting coralline algae (Miller 1985, Scheibling 1986). Shifts between these 2 states are driven by destructive grazing of kelp beds by sea urchins, which produces barrens, and mass mortality of sea urchins caused by amoebic disease, which allows kelps to re-establish (Scheibling et al. 1999, Lauzon-Guay et al. 2009). The alternation between 2 dramatically different states in this ecosystem makes it an ideal model system for studying the changes in 
the macrofaunal assemblage associated with loss and recovery of kelp beds. We began monitoring community composition at a representative site off Nova Scotia in 1992, when the system was in transition from the kelp bed to the barrens state, to test the hypothesis that the macrofaunal assemblage would differ between alternative states. We predicted that mesograzers of kelp (e.g. snails) and holdfastassociated invertebrates (e.g. brittle stars, amphipods) would be more abundant in the kelpdominated state and that sea urchins and mesograzers of coralline algae (e.g. chitons and limpets) would be more abundant in barrens.

In the mid-1990s, facilitative interactions of 2 invasive species disrupted the historical kelp-barrens cycle. The kelp-encrusting bryozoan Membranipora membranacea made kelp blades brittle and susceptible to breakage in winter storms, and severe outbreaks in 1993, 1997 and 1999 resulted in extensive defoliation of kelp beds off the Atlantic coast of Nova Scotia (Scheibling \& Gagnon 2009). Space created by kelp defoliation, and absence of urchin grazing pressure due to amoebic disease, allowed colonisation of the opportunistic green alga Codium fragile ssp. fragile (previously C. fragile ssp. tomentosoides, Provan et al. 2008; hereinafter C. fragile), which established extensive stands in former kelp beds (Scheibling \& Gagnon 2006, 2009, Watanabe et al. 2009). This provided an opportunity to extend our observations and analyses to include a third community configuration and to test the hypothesis that the macrofaunal assemblage associated with the $C$. fragile-dominated state would differ from the kelpdominated state in having fewer grazers, because $C$. fragile is less palatable than kelp (Lyons et al. 2007), and more small-bodied and juvenile invertebrates because the bushy morphology of $C$. fragile provides a complex habitat architecture that favours these species (Schmidt \& Scheibling 2006).

The alternation of kelp beds and urchin barrens is well described in Nova Scotia and other temperate rocky subtidal systems (Nova Scotia: Miller 1985, Scheibling 1986, Johnson \& Mann 1988, Scheibling et al. 1999; southern California: Ebeling et al. 1985; Gulf of Maine: Ojeda \& Dearborn 1989; New Zealand: Babcock et al. 1999; Aleutian Islands: Konar \& Estes 2003) and is often cited as an example of alternative stable states (Knowlton 2004, Hughes et al. 2005, Baskett \& Salomon 2010). The addition of a C. fragile-dominated state allowed us to examine the response of invertebrate assemblages to another dramatic shift in dominant macroalgae. We documented changes in community composition that occurred with each state shift in a rocky subtidal ecosystem off Nova Scotia from 1992 to 2008. We describe community composition along subtidal transects which, over the course of our study, included kelp- or C. fragiledominated states, barrens, and transitional states between these. Long-term studies such as this one are important for providing relevant baselines from which to measure ecological change, understanding community dynamics associated with shifts between alternative stable states, and examining ecosystem resilience (Knowlton 2004, Watson \& Estes 2011).

\section{MATERIALS AND METHODS}

\section{Study site}

We conducted our study on the leeward side of Little Duck Island $\left(44^{\circ} 22^{\prime} \mathrm{N}, 64^{\circ} 11^{\prime} \mathrm{W}\right)$ at the mouth of Mahone Bay, Nova Scotia. The substratum at this site consists of broad ridges of basaltic bedrock from the intertidal to $\sim 10 \mathrm{~m}$ below mean lower low water (MLLW), beyond which is an extensive cobble bed. Numerous studies at this site have focused on interactions involving the sea urchin Strongylocentrotus droebachiensis and macroalgae (e.g. Scheibling \& Hennigar 1997, Scheibling et al. 1999, Scheibling \& Gagnon 2006, 2009).

\section{Field sampling}

We sampled along 2 belt transects $(4 \times 50 \mathrm{~m})$ in 1992: one in a kelp bed at $6 \mathrm{~m}$ depth, and one in barrens offshore from the kelp bed at $8 \mathrm{~m}$ depth. Transects were staggered by $\sim 4 \mathrm{~m}$ in the offshore direction in each subsequent year to preclude overlap of sampling areas among years. To measure biomass of the algal canopy and abundance and biomass of large invertebrates, we sampled 8 to 10 random $1 \mathrm{~m}^{2}$ quadrats along the transects using SCUBA at 6 and $8 \mathrm{~m}$ depth in July, August or early September in each year from 1992 to 1998 (except 1996). In 1999, we added a transect at $4 \mathrm{~m}$ depth, to capture the establishment of Codium fragile in shallow water, and sampled the transect at $8 \mathrm{~m}$. We sampled transects at 4,6 and $8 \mathrm{~m}$ in 2000 and 2002, and at 4 and $8 \mathrm{~m}$ in 2008.

From each $1 \mathrm{~m}^{2}$ quadrat, divers collected all canopy-forming macroalgae (kelps, Codium fragile, Desmarestia spp. and Fucus spp.) and all large macroinvertebrates (generally these consisted of sea stars, sea urchins, periwinkles, whelks, mussels, crabs and large polychaetes). Algae were identified 
and weighed (wet weight) upon collection, and invertebrates were frozen and returned to the laboratory for identification and measurement. We measured biomass of turf-forming algae and abundance and biomass of small macroinvertebrates by collecting these organisms in a $0.1 \mathrm{~m}^{2}$ quadrat, inset in each $1 \mathrm{~m}^{2}$ quadrat, using an airlift suction device. These samples were frozen and returned to the laboratory for further processing. We did not measure the abundance of encrusting coralline algae of the genera Lithothamnion, Clathromorphum and Phymatolithon, which effectively covered the rock surfaces and were overgrown by turf- and canopy-forming macroalgae.

\section{Sample processing}

Wet weights of canopy-forming macroalgae obtained in the field were converted to dry weight (Table S1 in Supplement 1 at www.int-res.com/ articles/suppl/m437p069_supp.pdf). Samples from the $0.1 \mathrm{~m}^{2}$ quadrats were thawed in seawater and passed through a $1 \mathrm{~mm}$ sieve to remove sand and smaller invertebrates. Smaller macroalgae were sorted into the following categories: Codium fragile, the articulated coralline alga Corallina officinalis, red filamentous and plumose algae, red foliose algae (mainly Chondrus crispus), foliose and fleshy brown algae, and green algae other than $C$. fragile. These were oven-dried at $60^{\circ} \mathrm{C}$ until weight was constant, usually for $\sim 72 \mathrm{~h}$.

Invertebrates were identified to species where practical, and to genus or family otherwise (e.g. amphipods, isopods and Musculus spp. bivalves to genus; polychaetes to family). We recorded shell length of chitons, snails and bivalves, carapace length of hermit crabs, carapace width of brachyuran crabs, body length of polychaete worms, arm length of sea stars, test diameter of sea urchins, and disc diameter of brittle stars. Dry weights of these taxa $(\mathrm{n}=18)$ were estimated from size measurements using linear-regression equations (Table S2 in Supplement 1). For small abundant taxa $(\mathrm{n}=9$; e.g. small gastropods Lacuna vincta and Margarites groenlandicus, amphipods), pooled samples of individuals were weighed to estimate the average dry weight per individual. Rare taxa $(\mathrm{n}=18)$ were counted only. Thus, all analyses based on invertebrate biomass included 27 taxa (Table S3 in Supplement 2 at www.int-res.com/articles/suppl/m437p069_supp. pdf), and those based on invertebrate density included 45 taxa (Table S4 in Supplement 2).
For taxa that were frequently collected in both quadrat sizes $\left(0.1\right.$ and $\left.1 \mathrm{~m}^{2}\right)$ and included a mix of small- and large-bodied individuals (Strongylocentrotus droebachiensis, Asterias spp., Henricia sanguinolenta, Ophiopholis aculeata, Ophiura spp., Modiolus modiolus, Buccinum undatum and Cancer spp.), we examined the size-frequency distribution of individuals in the 2 quadrat sizes for each transect in each year to determine the sampling scale(s) that would best estimate abundance. Where there was little or no overlap in size-frequency distribution between the 2 quadrat sizes (e.g. juveniles in $0.1 \mathrm{~m}^{2}$ and adults in $1 \mathrm{~m}^{2}$ ), we used the formula:

$$
X_{i}=10\left(x_{i, 0.1}\right)+X_{i, 1}
$$

where $X_{i}$ is the abundance (count or mass) per $\mathrm{m}^{2}$ of a taxon in quadrat $i_{i} x_{i, 0.1}$ is the abundance in the $0.1 \mathrm{~m}^{2}$ inset; and $X_{i, 1}$ is the abundance in the $1 \mathrm{~m}^{2}$ quadrat. Where size-frequency distributions for the 2 quadrat sizes overlapped and the count in $1 \mathrm{~m}^{2}$ was $>5$ times the count in $0.1 \mathrm{~m}^{2}$ (suggesting that the 2 quadrat sizes sampled the same-sized individuals with roughly equal precision and a more detailed inspection would not yield additional small individuals), or the total number of individuals in each size class was $\leq 3$, we used the formula:

$$
X_{i}=x_{i, 0.1}+X_{i, 1}
$$

(Note that larger animals were removed from the $0.1 \mathrm{~m}^{2}$ inset when the $1 \mathrm{~m}^{2}$ quadrat was sampled, so these are not included in suction samples of the inset quadrat.) Where size-frequency distributions for the 2 quadrat sizes overlapped but the count in $1 \mathrm{~m}^{2}$ was $<5$ times the count in $0.1 \mathrm{~m}^{2}$ (suggesting that most individuals were too small to be effectively sampled in the $1 \mathrm{~m}^{2}$ quadrat), we used the formula:

$$
X_{i}=10\left(X_{i, 0.1}\right)
$$

\section{Statistical analyses}

Prior to data analysis, we culled the original data set to eliminate rare species $(<10$ ind. in total from all $10 \mathrm{yr}$ ) and those that had been identified only in 1 year, to reduce the potential error of species misidentification among multiple observers. Biomass of all non-coralline turf algae (i.e. excluding Corallina officinalis) was pooled for analysis. All statistical analyses were performed using an average (biomass or density per $\mathrm{m}^{2}$ ) of all quadrats for each transect in a given year.

Because values for biomass and density span several orders of magnitude, these data were 4th-root 
transformed prior to multivariate analysis. BrayCurtis similarity matrices were calculated from transformed data. We used non-metric multidimensional scaling (MDS) on biomass of Saccharina longicruris, Laminaria digitata, Codium fragile, Desmarestia spp., Corallina officinalis and turf algae to classify the algal assemblages from each transect. A 1-way analysis of similarity percentages (SIMPER) was used to identify algal taxa important in distinguishing assemblages.

We also used MDS to examine patterns based on invertebrate biomass (27 taxa). A 1-way analysis of similarity (ANOSIM), with algal assemblage type identified by the MDS of algae as the factor, was used to test for significant differences among invertebrate assemblages associated with each algal assemblage type. One-way SIMPER, with the same factor, was used to identify taxa important in distinguishing the invertebrate assemblages associated with each algal assemblage. We calculated the Shannon diversity index $\left(H^{\prime}\right)$ and Pielou's evenness index $\left(J^{\prime}\right)$ for each transect in each year, and compared values using 1way ANOVA with algal assemblage type as the factor. Tukey's honestly significant difference (HSD) test was used for post hoc comparisons. We repeated these analyses for invertebrate density (45 taxa). All multivariate analyses were carried out using Plymouth Routines in Multivariate Ecological Research (PRIMER) software, version 6 (Clarke \& Gorley 2006).

\section{RESULTS}

\section{Algal assemblages}

At the beginning of our study in 1992, the transect at $6 \mathrm{~m}$ spanned a kelp bed consisting mainly of $S a C$ charina longicruris, with a smaller biomass of plumose brown algae Desmarestia spp. (Fig. 1). The $8 \mathrm{~m}$ transect, in the wake of a dense grazing front of Strongylocentrotus droebachiensis (>200 urchins $\mathrm{m}^{-2}$, Scheibling et al. 1999), spanned urchin barrens characterised by very low biomass (mainly Corallina officinalis) of non-encrusting algae. Outbreaks of 2 non-indigenous species occurred in 1993: the pathogenic amoeba Paramoeba invadens, which causes disease and mass mortality in Strongylocentrotus droebachiensis (Scheibling \& Hennigar 1997), and the encrusting bryozoan Membranipora membranacea, which increases erosion of kelp blades and breakage during winter storms (Scheibling et al. 1999). Amoebic disease resulted in $87 \%$ urchin mortality by October 1993 (Scheibling \& Hennigar 1997).

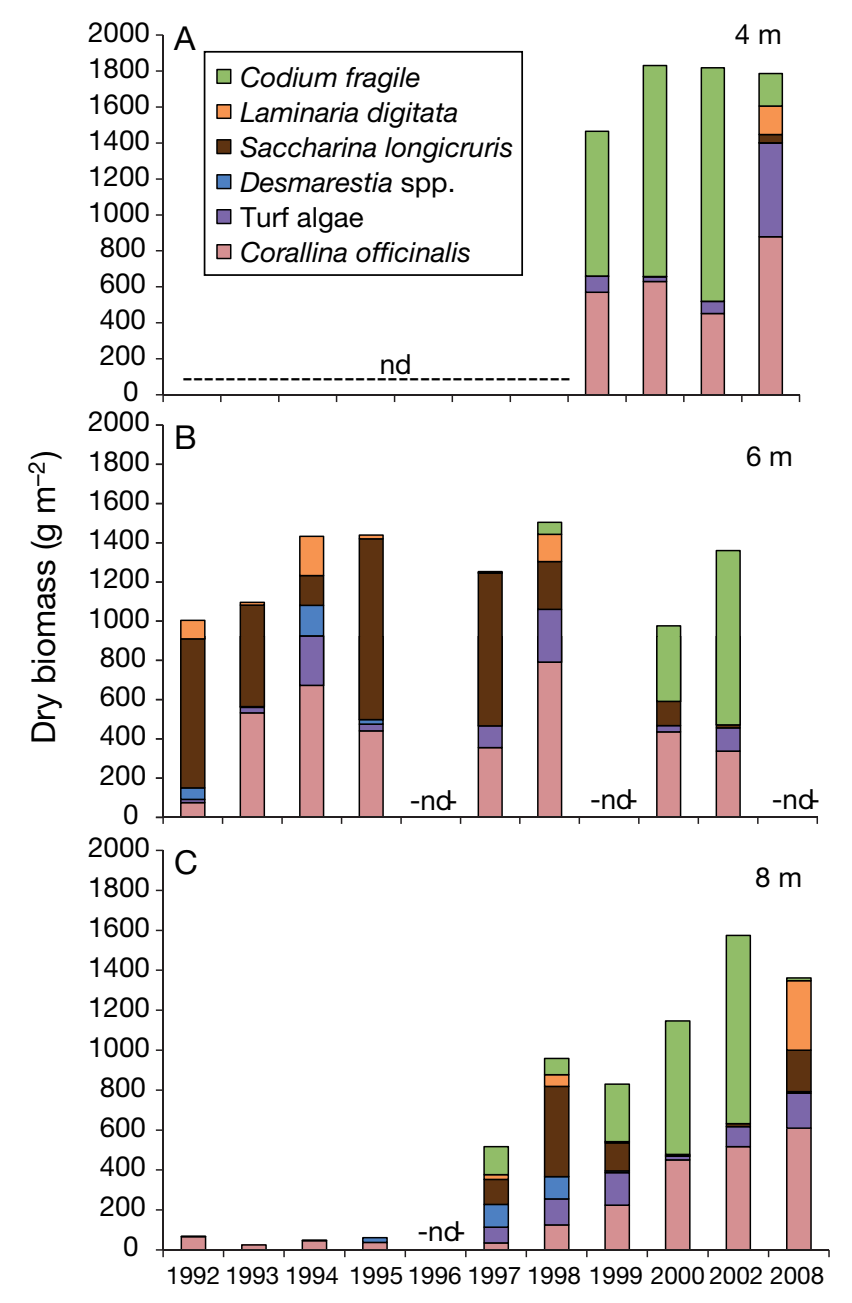

Fig. 1. Mean biomass of macroalgal species and functional groups in transects at (A) 4, (B) 6 and (C) $8 \mathrm{~m}$ depth at Little Duck Island from 1992 to 2008. Depths not sampled in a given year are indicated as no data (nd)

Defoliation following $M$. membranacea infestation caused biomass of Saccharina longicruris to decrease at $6 \mathrm{~m}$ between 1993 and 1994, while biomass of C. officinalis increased (Fig. 1).

The loss of the kelp canopy allowed the invasive alga Codium fragile to establish in shallow $(<5 \mathrm{~m}$ depth) water nearshore (Scheibling \& Gagnon 2006). By 1995, in the absence of destructive grazing, biomass of Saccharina longicruris at $6 \mathrm{~m}$ recovered to 1992 levels (Fig. 1). However, a second outbreak of Paramoeba invadens in 1995 caused almost complete mortality of sea urchins by October (Scheibling \& Hennigar 1997). Algal biomass at $8 \mathrm{~m}$ remained low through 1995, and then increased by 1997 with the growth of turf algae and Desmarestia spp., and with growth of $S$. longicruris and Corallina officinalis by 1998. In autumn 1997, another outbreak of Membra- 
nipora membranacea occurred, resulting in a decrease in biomass of $S$. longicruris at $6 \mathrm{~m}$ by 1998 . C. fragile first appeared at the 6 and $8 \mathrm{~m}$ transects between 1997 and 1998 (Fig. 1), and increased in biomass at all depths until 2002, while biomass of kelps and Desmarestia spp. remained low. By the end of the study in 2008, biomass of $C$. fragile had decreased, and transects at both 4 and $8 \mathrm{~m}$ depth were dominated by kelps (mainly Laminaria digitata) with an understory of $C$. officinalis and mixed turf algae (Fig. 1).

MDS using algal biomass data separated transects at different depths and in different years into 4 clusters that differed significantly from each other (ANOSIM: $\mathrm{R}=0.891, \mathrm{p}<0.001$ ) (Fig. 2A). SIMPER identified the algae that characterised each cluster: (1) the 'barrens' cluster included transects at $8 \mathrm{~m}$
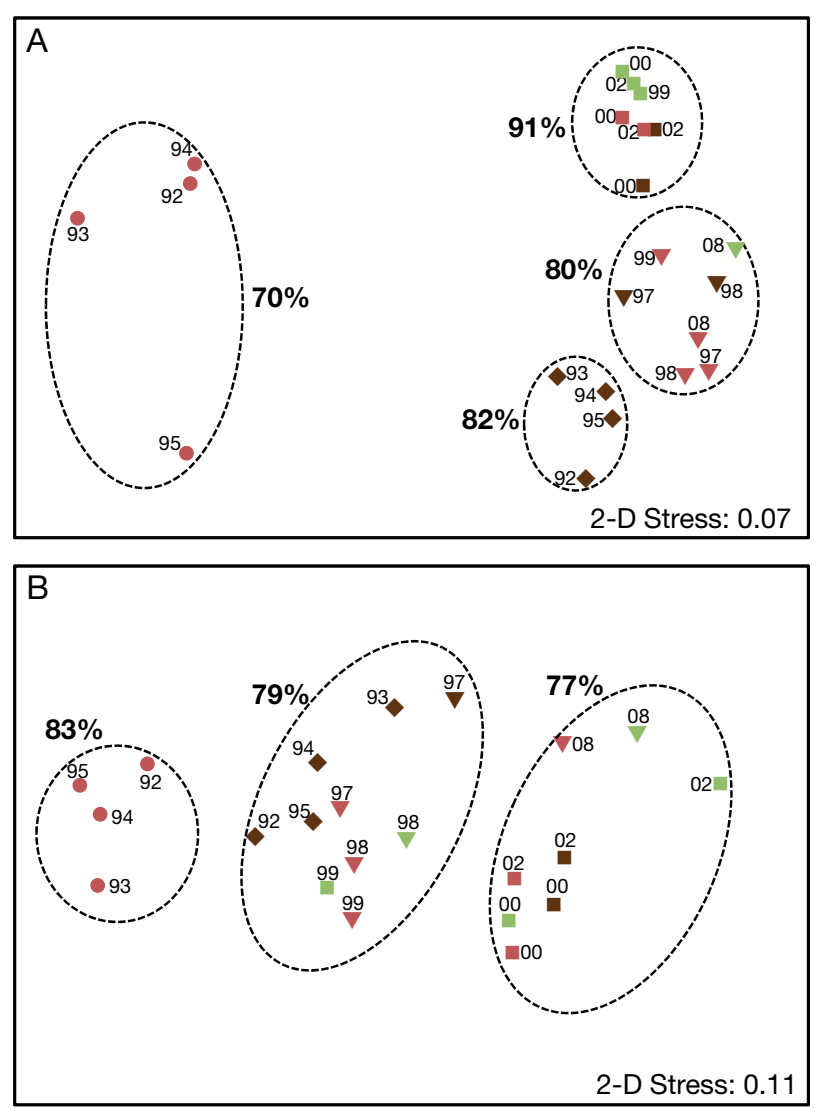

Fig. 2. Multidimensional scaling (MDS) plots of Bray-Curtis similarities of transects based on (A) algae and (B) invertebrates (4th-root transformed dry biomass, $\mathrm{g} \mathrm{m}^{-2}$ ). Data labels indicate year (1992 to 2008). Ellipses (dashed lines) indicate homogeneous clusters as determined by ANOSIM ( $p<0.001)$; percent similarity within each cluster is given in bold. Symbols indicate algal assemblage type: barrens (•), kelp-dominated $(\bullet)$, Codium fragile-dominated $(\boldsymbol{\bullet})$ and transitional ( $\mathbf{v})$. Colours indicate depth: $8 \mathrm{~m}$ (dark pink), $6 \mathrm{~m}$ (brown) and $4 \mathrm{~m}$ (green) from 1992 to 1995 and was distinguished by the presence of coralline alga Corallina officinalis and the absence of other non-encrusting macroalgae; (2) the 'kelp-dominated' cluster included the transects at $6 \mathrm{~m}$ from 1992 to 1997, and was characterised by relatively high biomass of Saccharina longicruris; (3) the 'transitional' cluster included transects at $8 \mathrm{~m}$ from 1997 to 1999, $6 \mathrm{~m}$ in 1997 and 1998, and 4 and $8 \mathrm{~m}$ in 2008 and had a mixture of algae including $S$. longicruris, Laminaria digitata, Codium fragile, and turf algae; $(4)$ the ' $C$. fragile-dominated' cluster included the transect at $4 \mathrm{~m}$ in 1999 and all transects from 2000 and 2002 and was characterised by a relatively high biomass of $C$. fragile (Table S5 in Supplement 3 at www.int-res.com/articles/suppl/m437p069_ supp.pdf). Algal diversity was not significantly different among the 4 clusters (Shannon diversity index, ANOVA: $F_{3,18}=2.157, \mathrm{p}=0.130$ ). Pielou's evenness index was significantly different among clusters $\left(F_{3,18}=3.901, \mathrm{p}=0.026\right)$ and was lower in the barrens cluster than in the kelp- and C. fragile-dominated clusters (Tukey's HSD test: $\mathrm{p}<0.05$ ). Both diversity and evenness at 6 and $8 \mathrm{~m}$ increased in 1994 after the outbreak of Paramoeba invadens and Membranipora membranacea in the previous year, and decreased in the early 2000s following the increase in C. fragile biomass in 1999.

\section{Invertebrate assemblages}

MDS using biomass of 27 invertebrate taxa separated transects into groups that corresponded generally with those identified using algae, except that kelp and transitional transects formed one cluster, and the 2008 transects were classified with the Codium fragile-dominated cluster (Fig. 2B). Algal assemblage type was highly significant in separating invertebrate assemblages (ANOSIM: $\mathrm{R}=0.549, \mathrm{p}<$ 0.001). Pairwise comparisons showed that the transitional cluster was similar to both the kelp- and C. fragile-dominated clusters (ANOSIM: $\mathrm{R}=0.243$, $\mathrm{p}=0.09$ for kelp vs. transitional; $\mathrm{R}=0.25, \mathrm{p}=0.03$ for C. fragile vs. transitional). SIMPER analysis identified the sea urchin Strongylocentrotus droebachiensis, gastropod Lacuna vincta, mussel Modiolus modiolus and brittle star Ophiopholis aculeata as contributing the most to differences between pairs of invertebrate assemblages (Table S6 in Supplement 3). Biomass of $S$. droebachiensis was highest in barrens transects, $L$. vincta in transitional and kelp-dominated transects, $M$. modiolus in $C$. fragiledominated and transitional transects, and O. aculeata 
in barrens and transitional transects (Table S6 in Supplement 3). The invertebrate assemblage at $4 \mathrm{~m}$ in 1999 was dominated by $M$. modiolus (>2000 $\mathrm{g} \mathrm{m}^{-2}$ ) but was otherwise similar to those associated with kelp-dominated and transitional assemblages at other depths, including molluscan grazers (chitons, limpets, and other small gastropods), juvenile sea urchins, sea stars Asterias spp., and brittle stars Amphipholis squamata and $O$. aculeata. Results of MDS using density of 45 invertebrate taxa were similar to those obtained using biomass. SIMPER analysis identified amphipods Gammarus spp., L. vincta, S. droebachiensis, and the gastropod Margarites groenlandicus as contributing the most to differences between pairs of invertebrate assemblages (Table S7 in Supplement 3). Gammarus spp. were most numerous in C. fragile-dominated transects, L. vincta and M. groenlandicus in transitional transects, and S. droebachiensis in barrens transects (Table S7 in Supplement 3).

Invertebrate taxonomic richness differed among transect types (ANOVA: $F_{3,18}=4.80, \mathrm{p}=0.013$ ) and was significantly lower in barrens $(26.5 \pm 1.0 \mathrm{SE}$ taxa) than in Codium fragile-dominated (33.1 \pm 1.1 taxa) and kelp-dominated (35.0 \pm 1.5 taxa) transects; transitional transects $(32.4 \pm 2.2$ taxa $)$ did not differ significantly from others in taxonomic richness (Tukey's HSD test, $\alpha=0.05$ for all pairwise comparisons). The Shannon diversity index differed significantly among transect types (ANOVA: $F_{3,18}=5.15, \mathrm{p}=0.01$ ) and was significantly lower in barrens than in kelpdominated transects (Tukey's HSD test, $\mathrm{p}=0.013$; $\mathrm{p}>$ 0.05 for all other pairwise comparisons). Pielou's evenness index did not differ among transect types (ANOVA: $F_{3,18}=2.41, \mathrm{p}=0.101$ ). Most taxa were found in all transect types, but some relatively rare taxa were exceptions to this: the gastropod Onoba aculeus was found only in $C$. fragile transects, and the sea cucumber Chiridota laevis and the bivalve Clinocardium ciliatum were absent from $C$. fragile transects; the gastropod Hydrobia minuta and the ascidian Molgula sp. were absent from barrens; the chiton Tonicella marmorea was found only in transitional transects and the crab Hyas coarctatus was absent from transitional transects (Table S4 in Supplement 2).

Invertebrate biomass from 1992 to 1995 was dominated by Strongylocentrotus droebachiensis, Modiolus modiolus and brittle stars at 6 and $8 \mathrm{~m}$ (Fig. 3). Biomass of $S$. droebachiensis had declined sharply by 1997, following the 1995 outbreak of Paramoeba invadens, and had not recovered by the end of the study in 2008. The relatively long-lived and heavy- shelled $M$. modiolus dominated invertebrate biomass at these depths after the sea urchin mass mortality, and at $4 \mathrm{~m}$ from 1999 to 2008 (Fig. 3). Biomass of mesograzers of coralline algae (chitons Ischnochiton

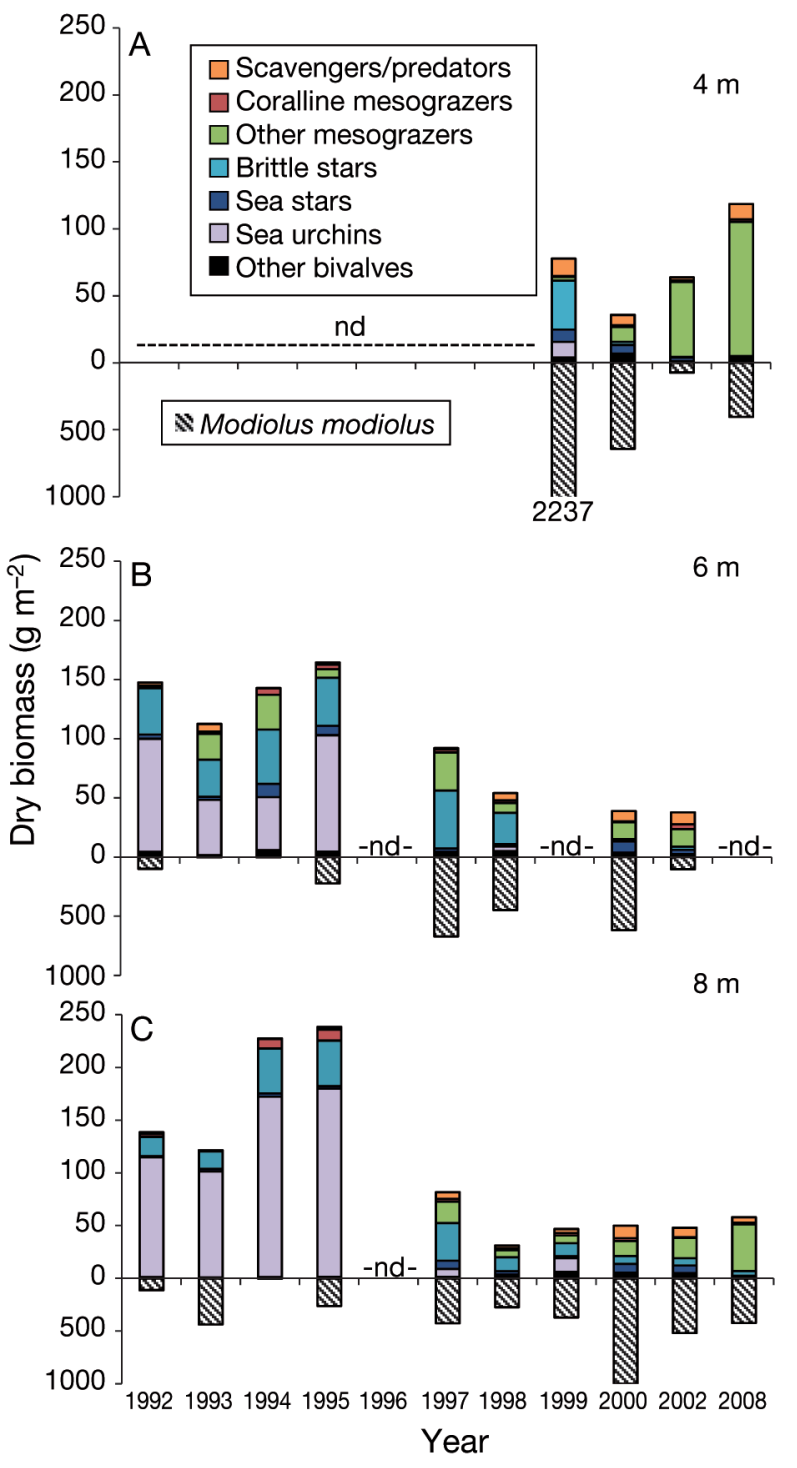

Fig. 3. Mean biomass of invertebrate taxa and functional groups in transects at (A) 4, (B) 6 and (C) 8 m depth at Little Duck Island from 1992 to 2008. Scavenger/predator group includes hermit crab Pagurus acadiensis, crab Cancer irroratus, and scale worms (Polynoidae). Coralline mesograzer group includes limpet Testudinalia testudinalis and chitons Ischnochiton albus and I. ruber. Other mesograzer group includes amphipods Caprella spp. and Gammarus spp. and snails Lacuna vincta and Littorina littorea. Biomass of mussel Modiolus modiolus was frequently an order of magnitude greater than that of other taxa and is shown on the lower portion of the $y$-axis on a different scale. Total biomass of $M$. modiolus $\left(\mathrm{g} \mathrm{m}^{-2}\right.$ ) in the truncated bar (4 $\mathrm{m}$ in 1999) is given below the bar. Depths not sampled in a given year are indicated as no data (nd) 
ruber and I. albus and limpet Testudinalia testudinalis) had declined by 1998 at 6 and $8 \mathrm{~m}$ and remained low thereafter, while biomass of several small-bodied species, including mussels Musculus spp., brittle stars Ophiura spp., and other mesograzers (amphipods Gammarus spp., gastropods Margarites groenlandicus and Lacuna vincta) increased (Fig. 3; Table S3 in Supplement 2). By 2008, amphipod (Caprella spp.), isopod (Idotea spp.), and gastropod (L. vincta, M. groenlandicus and Littorina littorea) mesograzers formed a large component of the biomass at 4 and $8 \mathrm{~m}$ (Table S3 in Supplement 2).

Temporal patterns of invertebrate density were similar to those of biomass for most species. A few taxa increased substantially in density, but not in biomass, in 1999 and 2000: Strongylocentrotus droebachiensis, brittle star Amphipholis squamata, and bivalves Modiolus modiolus, Musculus spp. and Anomia spp. Sea stars Henricia sanguinolenta and Asterias spp. increased in biomass, but not in density in 1999 and 2000, respectively (Table S3 in Supplement 2).

\section{DISCUSSION}

The shifts in macroalgal abundance and community composition at Little Duck Island between 1992 and 2008 - from kelp beds and barrens to a transitional state, to dominance of the invasive alga Codium fragile, and then back to a transitional state-were largely driven by the amoebic pathogen Paramoeba invadens and the encrusting bryozoan Membranipora membranacea. Overall differences in macrofaunal assemblages among kelp-dominated, barrens, and C. fragile-dominated transects were largely due to differences in relative abundance of various taxa rather than the presence of unique species in each state. Other studies along the Atlantic coast of Nova Scotia (Scheibling \& Raymond 1990, Schmidt \& Scheibling 2006, 2007, Knip \& Scheibling 2007) and Newfoundland (Himmelman et al. 1983) have observed considerable overlap in invertebrate species composition among different ecosystem states.

The differences in macrofaunal assemblages associated with barrens, kelp- and Codium fragiledominated ecosystem states at Little Duck Island likely reflected structural rather than trophic effects of changes in the dominant macroalgae. The shift from barrens to macroalgae-dominated states represented a dramatic increase in structural complexity and resulted in significantly higher invertebrate taxonomic richness and diversity. Other studies have shown that shifts in algal assemblages that result in changes in the physical structure of a habitat tend to have the most pronounced effects on macrofaunal assemblages. In the Mediterranean, the invasive alga Caulerpa racemosa caused increased sedimentation, which likely contributed to the shift from a gastropod- and crustacean-dominated assemblage to a polychaete-dominated one in seagrass beds (Posidonia oceanica) off Cyprus (Argyrou et al. 1999). In Patagonia, holdfasts of invasive Undaria pinnatifida support a less diverse invertebrate assemblage than do the larger holdfasts of native kelp Macrocystis pyrifera (Raffo et al. 2009).

Compared to the shift from barrens to macroalgaedominated states, the shift from kelp- to Codium fragile-dominated states represented a lesser shift in structural complexity and did not result in changes to taxonomic richness, diversity or evenness. Other studies have found minimal effects of invertebrate assemblages when dominant macroalgae have been replaced by structurally similar invasive species (Viejo 1999, Wernberg et al. 2004, Buschbaum et al. 2006, Thomsen et al. 2009). In the North Sea, the effects of the canopy-forming brown alga Sargassum muticum on invertebrate diversity differed among habitats (Buschbaum et al. 2006). On a sandy bottom, $S$. muticum enhanced structural complexity and increased diversity, while on rocky bottom the invasive alga had no effect on epifaunal species composition or diversity when compared to a native assemblage (Buschbaum et al. 2006). In Washington state, USA, S. muticum altered the native algal assemblage by shading native kelps and understory algae, but did not change water flow or sedimentation and had no effect on invertebrate species richness (BrittonSimmons 2004). Epifaunal mesograzer assemblages were similar between $S$. muticum and the structurally similar native brown algae Cystoseira nodicaulis in Spain (Viejo 1999) and Halidrys siliquosa in Denmark (Wernberg et al. 2004). The invasive kelp Undaria pinnatifida is structurally similar to native species and does not appear to affect benthic macrofaunal assemblages in New Zealand (Forrest \& Taylor 2002). In Patagonia, U. pinnatifida has begun to replace the native kelp Macrocystis pyrifera, but benthic faunal evenness and diversity do not appear to be affected by the dominant kelp species (Raffo et al. 2009). The apparent resilience of macroalgaeassociated invertebrate assemblages may be due to low host-plant specificity of many mobile invertebrates and the fact that many species graze epiphytes rather than the dominant macroalgae (Viejo 1999, Wernberg et al. 2004, Buschbaum et al. 2006). 
Although invertebrate diversity and taxonomic richness did not differ between kelp- and Codium fragile-dominated states at Little Duck Island, some finer-scale patterns indicate that morphological differences between the dominant macroalgae affected the macrofaunal assemblage. Amphipods and isopods were more abundant in $C$. fragile-dominated transects; fine utricle hairs create a complex microstructure to which amphipods cling (Hacker \& Steneck 1990, Schmidt \& Scheibling 2006). A sharp decrease in biomass of brittle star Ophiopholis aculeata was associated with dominance of $C$. fragile and the loss of kelp holdfasts, which provide habitat for larger brittle stars (Knip \& Scheibling 2007). Smaller-bodied brittle stars utilise coralline algae and other erect turf species for habitat. While there was an overall decrease in brittle star biomass because of the loss of larger individuals, there was no decrease in brittle star density in the $C$. fragile-dominated state. Sharp increases in density, but not biomass, of several species between 1999 and 2002, suggest that the bushy morphology of $C$. fragile altered water flow and promoted settlement of sea urchins, brittle stars and bivalves in the $C$. fragile-dominated state. The increase in biomass, but not density, of sea stars Asterias spp. in 2000 suggests that rates of growth or immigration of larger individuals increased with the availability of small bivalve prey. These changes to the invertebrate assemblage persisted to 2008, when the algal assemblage had returned to a transitional state. The greater biomass of Corallina officinalis and turf algae in 2008, as compared to the earlier transitional state, may have contributed to this disconnect between the macrofaunal and algal assemblages by creating microhabitat that favoured mesograzers over largerbodied brittle stars.

Our findings are generally similar to those of longterm studies in the Gulf of Maine. Harris \& Tyrrell (2001) and Levin et al. (2002) also describe benthic community changes at sites that historically alternated between kelp bed and barrens but have become dominated by Codium fragile. As in Nova Scotia, C. fragile occurred at low densities in kelp beds in the Gulf of Maine until defoliation of kelps by Membranipora membranacea allowed the invasive alga to form monospecific stands (Levin et al. 2002). However, community dynamics differ between the 2 regions in several ways: (1) the decline of sea urchin populations in the Gulf of Maine has been attributed largely to overfishing, and not to disease; (2) a cycle of mussel recruitment and sea-star predation in the Gulf of Maine, in addition to kelp defoliation by M. membranacea, created space for invasive species, including C. fragile; and (3) invasive tunicates Diplosoma listerianum and Botrylloides violaceus are conspicuous benthic species in the Gulf of Maine but not along the Atlantic coast of Nova Scotia (Harris \& Tyrrell 2001).

The decline of Codium fragile and increased kelp biomass by the end of our study in 2008 indicates a return to dominance of Laminaria digitata in the shallow subtidal zone as observed in the early 1990s (Scheibling \& Gagnon 2006). L. digitata is slowergrowing and longer-lived than Saccharina longicruris (Smith 1985), and the shift in kelp dominance may reflect a later successional stage. Alternatively, the shallow population of L. digitata may have provided a greater source of propagules to deeper water than stands of $S$. longicruris during the post- $C$. fragile transition. The decline of $C$. fragile likely began with increased fragmentation in winter storms as thalli grew larger and less able to withstand hydrodynamic forces (D'Amours \& Scheibling 2007). Removal of $C$. fragile results in increased kelp recruitment, and competitive interactions could have limited subsequent growth of the invasive alga and promoted kelp recovery (Scheibling \& Gagnon 2006). It is unlikely that grazing by sea urchins or other invertebrates contributed significantly to the decline of C. fragile, as it is a low-preference food both for sea urchins (Sumi \& Scheibling 2005) and the gastropod Lacuna vincta (Chavanich \& Harris 2002). Cover of C. fragile declined and cover of native kelps increased between 2000 and 2007 in St. Margarets Bay and Mahone Bay, Nova Scotia (Watanabe et al. 2010), indicating that the recovery of kelps we observed at Little Duck Island occurred at a larger spatial scale.

State shifts at Little Duck Island were driven by destructive grazing of kelps by sea urchins, mass mortality of sea urchins caused by amoebic disease, and defoliation of kelps following outbreaks of the encrusting bryozoan Membranipora membranacea. Changes in the macrofaunal assemblage with each state shift suggest that structural complexity of algae affects relative abundance of invertebrate functional groups. Like other invasive algae, Codium fragile may have been a 'passenger' of ecological change in that it colonised the rocky subtidal opportunistically following defoliation of kelps (Didham et al. 2005), but once established, it inhibited recruitment of native seaweeds (Scheibling \& Gagnon 2006) and caused changes in the macrofaunal assemblage. The kelp-dominated state could persist for years to decades until sea urchins recolonise the shallows and graze destructively, leading to a barrens state, or 
until another heavy infestation of $M$. membranacea causes kelp defoliation, creating space in the canopy for re-establishment and spread of $C$. fragile that potentially could shift the system back into a $C$. fragile-dominated state. The recovery of kelps suggests that despite being relatively species poor, the rocky subtidal ecosystem off the Atlantic coast of Nova Scotia has some degree of resilience when viewed at a decadal time scale.

Acknowledgements. We thank I. Dempsey, A. Hennigar, E. Scheibling, A. Schmidt, A. Metaxas and the many other divers who assisted us over the years; J. Lindley for use of his boat in 2008; I. Dempsey, P. Winger, S. Brady, R. Melady, A. Ryan and T. Wilson for help with sample processing; and P. Gagnon for assistance with data analysis and helpful discussions of the work. The research was continuously supported by Operating/Research/Discovery Grants from the Natural Sciences and Engineering Research Council of Canada (NSERC) to R.E.S.; J.R.K. was supported by a Dalhousie University Scholarship, a Killam pre-doctoral scholarship, and an NSERC Alexander Graham Bell Canada Graduate Scholarship.

\section{LITERATURE CITED}

Argyrou M, Demetropoulos A, Hadjichristophorou M (1999) Expansion of the macroalga Caulerpa racemosa and changes in softbottom macrofaunal assemblages in Moni Bay, Cyprus. Oceanol Acta 22:517-528

Babcock RC, Kelly S, Shears NT, Walker JW, Willis TJ (1999) Changes in community structure in temperate marine reserves. Mar Ecol Prog Ser 189:125-134

Baskett ML, Salomon AK (2010) Recruitment facilitation can drive alternative states on temperate reefs. Ecology 91: 1763-1773

Behrens MD, Lafferty KD (2004) Effects of marine reserves and urchin disease on southern Californian rocky reef communities. Mar Ecol Prog Ser 279:129-139

Britton-Simmons KH (2004) Direct and indirect effects of the introduced alga Sargassum muticum on benthic, subtidal communities of Washington State, USA. Mar Ecol Prog Ser 277:61-78

Buschbaum C, Chapman AS, Saier B (2006) How an introduced seaweed can affect epibiota diversity in different coastal systems. Mar Biol 148:743-754

Chavanich S, Harris LG (2002) The influence of macroalgae on seasonal abundance and feeding preference of a subtidal snail, Lacuna vincta (Montagu) (Littorinidae) in the Gulf of Maine. J Molluscan Stud 68:73-78

Clarke KR, Gorley RN (2006) PRIMER v6: user manual/ tutorial. PRIMER-E, Plymouth

$>$ D'Amours O, Scheibling R (2007) Effect of wave exposure on morphology, attachment strength and survival of the invasive green alga Codium fragile ssp. tomentosoides. J Exp Mar Biol Ecol 351:129-142

- Didham RK, Tylianakis JM, Hutchison MA, Ewers RM, Gemmell NJ (2005) Are invasive species the drivers of ecological change? Trends Ecol Evol 20:470-474

> Ebeling AW, Laur DR, Rowley RJ (1985) Severe storm disturbances and reversal of community structure in a southern California kelp forest. Mar Biol 84:287-294
Forrest BM, Taylor MD (2002) Assessing invasion impact: survey design considerations and implications for management of an invasive marine plant. Biol Invasions 4: 375-386

> Graham MH (2004) Effects of local deforestation on the diversity and structure of southern California giant kelp forest food webs. Ecosystems 7:341-357

Hacker SD, Steneck RS (1990) Habitat architecture and the abundance and body-size-dependent habitat selection of a phytal amphipod. Ecology 71:2269-2285

Harris LG, Tyrrell MC (2001) Changing community states in the Gulf of Maine: synergism between invaders, overfishing and climate change. Biol Invasions 3:9-21

Himmelman JH, Cardinal A, Bourget E (1983) Community development following removal of urchins, Strongylocentrotus droebachiensis, from the rocky subtidal zone of the St. Lawrence Estuary, Eastern Canada. Oecologia 59: 27-39

Hughes TP, Bellwood DR, Folke C, Steneck RS, Wilson J (2005) New paradigms for supporting the resilience of marine ecosystems. Trends Ecol Evol 20:380-386

Johnson CR, Mann KH (1988) Diversity, patterns of adaptation, and stability of Nova Scotian kelp beds. Ecol Monogr 58:129-154

Knip DM, Scheibling RE (2007) Invertebrate fauna associated with kelp enhances reproductive output of the green sea urchin Strongylocentrotus droebachiensis. J Exp Mar Biol Ecol 351:150-159

Knowlton N (2004) Multiple 'stable' states and the conservation of marine ecosystems. Prog Oceanogr 60:387-396

Konar B, Estes JA (2003) The stability and boundary regions between kelp beds and deforested areas. Ecology 84: 174-185

Lauzon-Guay JS, Scheibling RE, Barbeau MA (2009) Modelling phase shifts in a rocky subtidal ecosystem. Mar Ecol Prog Ser 375:25-39

Levin PS, Coyer JA, Petrik R, Good TP (2002) Communitywide effects of nonindigenous species on temperate rocky reefs. Ecology 83:3182-3193

Lyons DA, Van Alstyne KL, Scheibling RE (2007) Anti-grazing activity and seasonal variation of dimethylsulfoniopropionate-associated compounds in the invasive alga Codium fragile ssp. tomentosoides. Mar Biol 153:179-188

Miller RJ (1985) Succession in sea urchin and seaweed abundance in Nova Scotia, Canada. Mar Biol 84:275-286

> Ojeda FP, Dearborn JH (1989) Community structure of macroinvertebrates inhabiting the rocky subtidal zone in the Gulf of Maine: seasonal and bathymetric distribution. Mar Ecol Prog Ser 57:147-161

> Provan J, Booth D, Todd NP, Beatty GE, Maggs CA (2008) Tracking biological invasions in space and time: elucidating the invasive history of the green alga Codium fragile using old DNA. Divers Distrib 14:343-354

Raffo MP, Eyras MC, Iribarne OO (2009) The invasion of Undaria pinnatifida to a Macrocystis pyrifera kelp in Patagonia (Argentina, south-west Atlantic). J Mar Biol Assoc UK 89:1571-1580

Scheibling RE (1986) Increased macroalgal abundance following mass mortalities of sea urchins (Strongylocentrotus droebachiensis) along the Atlantic coast of Nova Scotia. Oecologia 68:186-198

Scheibling RE, Gagnon P (2006) Competitive interactions between the invasive green alga Codium fragile ssp. tomentosoides and native canopy-forming seaweeds in Nova Scotia (Canada). Mar Ecol Prog Ser 325:1-14 
Scheibling RE, Gagnon P (2009) Temperature-mediated outbreak dynamics of the invasive bryozoan Membranipora membranacea in Nova Scotian kelp beds. Mar Ecol Prog Ser 390:1-13

Scheibling RE, Hennigar AW (1997) Recurrent outbreaks of disease in sea urchins Strongylocentrotus droebachiensis in Nova Scotia: evidence for a link with large-scale meteorologic and oceanographic events. Mar Ecol Prog Ser 152:155-165

Scheibling RE, Raymond BG (1990) Community dynamics on a subtidal cobble bed following mass mortalities of sea urchins. Mar Ecol Prog Ser 63:127-145

Scheibling RE, Hennigar AW, Balch T (1999) Destructive grazing, epiphytism, and disease: the dynamics of sea urchin-kelp interactions in Nova Scotia. Can J Fish Aquat Sci 56:2300-2314

Schmidt AL, Scheibling RE (2006) A comparison of epifauna and epiphytes on native kelps (Laminaria spp.) and the invasive green alga (Codium fragile ssp. tomentosoides) in Nova Scotia, Canada. Bot Mar 49:315-330

Schmidt AL, Scheibling RE (2007) Effects of native and invasive macroalgal canopies on composition and abundance of mobile benthic macrofauna and turf-forming algae. J Exp Mar Biol Ecol 341:110-130

Smith BD (1985) Recovery following experimental harvesting of Laminaria longicruris and $L$. digitata in southwestern Nova Scotia. Helgol Meeresunters 39:83-101

Steneck RS, Graham MH, Bourque BH, Corbett D, Erlandson JM, Estes JA, Tegner MJ (2002) Kelp forest ecosystems: biodiversity, stability, resilience and future. Environ Conserv 29:436-459

Editorial responsibility: Morten Pedersen,

Roskilde, Denmark
Strong JA, Dring MJ, Maggs CA (2006) Colonisation and modification of soft substratum habitats by the invasive macroalga Sargassum muticum. Mar Ecol Prog Ser 321: 87-97

Sumi CBT, Scheibling RE (2005) Role of grazing by sea urchins Strongylocentrotus droebachiensis in regulating the invasive alga Codium fragile ssp. tomentosoides in Nova Scotia. Mar Ecol Prog Ser 292:203-212

> Thomsen MS, Wernberg T, Tuya F, Silliman BR (2009) Evidence for impacts of nonindigenous macroalgae: a metaanalysis of experimental field studies. J Phycol 45: 812-819

> Viejo RM (1999) Mobile epifauna inhabiting the invasive Sargassum muticum and two local seaweeds in northern Spain. Aquat Bot 64:131-149

Watanabe S, Metaxas A, Scheibling RE (2009) Dispersal potential of the invasive green alga Codium fragile ssp. fragile. J Exp Mar Biol Ecol 381:114-125

Watanabe S, Scheibling RE, Metaxas A (2010) Contrasting patterns of spread in interacting invasive species: Membranipora membranacea and Codium fragile off Nova Scotia. Biol Invasions 12:2329-2342

> Watson J, Estes JE (2011) Stability, resilience and phase shifts in rocky subtidal communities along the west coast of Vancouver Island, Canada. Ecol Monogr 81: 215-239

> Wernberg T, Thomsen MS, Staehr PA, Pedersen MF (2004) Epibiota communities of the introduced and indigenous macroalgal relatives Sargassum muticum and Halidrys siliquosa in Limfjorden (Denmark). Helgol Mar Res 58: 154-161

Submitted: September 22, 2010; Accepted: July 5, 2011

Proofs received from author(s): August 26, 2011 